Roger Blanpain*

\title{
Freedom of Services in the EU and the Use of Languages
}

$\mathcal{O}$ anguages problems also arise within the freedom of services and es-
pecially when an employer of one Member State puts one or more of his workers at the disposal of another employer in another Member State of the EU. This issue was addressed by a Directive of 16 December 1996, whereby was indicated which working conditions apply to the worker in the host country where he works. A new directive of 2014 concerns the enforcement of the 1996 directive and addresses also language problems: namely in which language necessary information has to be given. We first provide an insight in the 1996 directive.

\section{Posting of Workers: Directive 96/71 of 16 December 1996}

\subsection{Scope of application}

The directive applies to undertakings, established in a Member State, which post workers for a limited period (Article 2[1]) in the framework of transnational services to the territory of a Member State (Article 1[1]) other than the Member State in which the worker works normally (Art. 2[1]) in the framework of either:

- subcontracting;

- a group;

- temporary work for a user (Art. 1[3]).

The notion of worker is that which applies in the law of the Member State to whose territory the worker is posted (Art. 2[2]).

* Professor Emeritus at the Catholic University of Leuven, Professor at the Law Faculty of the University of Tilburg. 
The merchant navy undertakings are excluded as regards seagoing personnel (Article 1[2]).

The hiring-out of workers, within the meaning of Article 1(3)(c) of Directive 96/71, is a service provided for remuneration in respect of which the worker who has been hired out remains in the employment of the undertaking providing the service, no contract of employment being entered into with the user undertaking. It is characterised by the fact that the movement of the worker to the host Member State constitutes the very purpose of the provision of services effected by the undertaking providing the services and that that worker carries out his tasks under the control and direction of the user undertaking.

How many workers are posted in the EU?

The only harmonised method of measuring how many workers are posted from one Member State to another is based on the number of social security certificates issued for postings to another country. When a worker is posted for up to 24 months to another country, and subject to additional conditions being fulfilled, a 'portable document A1' (PDA1, previously known as E101) is issued to certify which social security legislation applies to the holder. The last data available is for 2011.

Based on the number of PDA1 issued, in 2011, the main sending countries of posted workers were Poland, Germany and France followed by Romania, Hungary, Belgium and Portugal.

The main receiving countries were Germany and France followed by the Netherlands, Belgium, Spain, Italy and Austria.

PD A1 issued for posting from the top 3 sending countries:

- Poland 228,000

- Germany 227,000

- France 144,000.

Four other countries (BE, RO, HU and PT) recorded a number higher than 50,000 and six others (ES, SI, SK, LU, IT, UK) issued between 30,000 and 50,000 PD A1 for postings. Numbers in most other countries were substantially lower.

Countries receiving the highest number of posted workers in 2011:

- Germany 311,000

- France 162,000

- Belgium 125,000

- Netherlands 106,000

Other countries which have received a substantial number $(30,000$ 80,000) of posted workers in 2011 were Austria, Italy, Switzerland, Spain, UK and Norway. 


\subsection{Terms and Conditions of Employment}

\section{A. Minimum Conditions}

Working conditions which apply and have to be guaranteed to posted workers are those laid down by:

- governmental rules;

- collective agreements or arbitration awards, generally binding, concerning building work, and

- other collective agreements or arbitration awards, generally binding, for other activities indicated by the Member State (Article 3[10]) concerning:

a. working time maximum work and minimum rest periods;

b. minimum paid annual vacation;

c. minimum wage including overtime;

d. rules concerning temporary work;

e. safety, health and hygiene at work;

f. protection of motherhood, children and youngsters;

g. equal treatment for men and women and other matters relating to nondiscrimination (Art. 3[1]).

There are minimum conditions. They can obviously be improved upon (Art. 3[7][1]).

\section{B. Other Conditions}

Member States can impose:

- working conditions relating to public order (e.g. forced labour);

- working conditions contained in generally binding collective agreements, other than construction, as indicated above (Article 3[10]).

These relate to the hard core of minimum conditions as indicated by Article 3, 1.

The same for the application of the conditions of employment, which are more favourable to workers, according to Article 3, 7; they concern the hard core and not other conditions.

Undertakings of the Member States should be treated equally (Article $3[10])$.

Undertakings from non-Member States cannot have a more favourable treatment than enterprises located in Member States (Article 1[4]).

Under the first indent of Article 3(10) of Directive 96/71 it is open to Member States, in compliance with the EU Treaty, to apply, in a non-discriminatory manner, to undertakings which post workers to their territory terms and conditions of employment on matters other than those referred to the first subparagraph of Article 3(1), in the case of public policy provisions. 
In that connection, it must be recalled that the classification of national provisions by a Member State as public order legislation applies to national provisions compliance with which has been deemed to be so crucial for the protection of the political, social or economic order in the Member State concerned as to require compliance therewith by all persons present on the national territory of that Member State and all legal relationships within that State.

Therefore the public policy exception is a derogation from the fundamental principle of freedom to provide services which must be interpreted strictly, the scope of which cannot be determined unilaterally by the Member States (see, regarding freedom of movement for persons).

In the context of Directive 96/71, the first indent of Article 3(10), constitutes a derogation from the principle that the matters with respect to which the host Member State may apply its legislation to undertakings which post workers to its territory are set out in an exhaustive list in the first subparagraph of Article 3(1) thereof. The first indent of Article 3(10) must therefore be interpreted strictly.

The expression 'public policy provisions' is to be construed as covering those mandatory rules from which there can be no derogation and which, by their nature and objective, meet the imperative requirements of the public interest.

Not falling as mandatory provisions falling under national public policy:

- the requirement of a written contract or document established pursuant to Directive 91/533;

- the requirement relating to the automatic adjustment of rates of remuneration to the cost of living;

- the requirement of equal treatment relating to the rules on part-time and fixed term work;

- the requirement relating to imperative provisions of national law in respect of collective agreements.

\section{Exceptions}

Possible exceptions are foreseen as follows.

a. In the case of initial assembly and/or first installation of goods where this is an integral part of a contract for the supply of goods necessary for taking the goods supplied into use and carried out by the skilled and/or specialist workers of the supplying undertaking, the first subparagraph of paragraph 1(b) (annual holidays) and (c) (minimum pay) shall not apply, if the period of posting does not exceed eight days.

This exception does not apply to activities in the field of building work.

b. Member States may, after consulting employers and labour, in accordance with the traditions and practices of each Member State, decide 
not to apply the first subparagraph of paragraph 1(c) (minimum pay) in the cases referred to in Article 1(3)(a) (subcontracting) and (b) (group) when the length of the posting does not exceed one month.

c. Member States may, in accordance with national laws and/or practices, provide that exemptions may be made from the first subparagraph of paragraph 1(c) (minimum pay) in the cases referred to in Article 1(3)(a) (subcontracting) and

d. (temporary work) and from a decision by a Member State regarding b) above, by means of generally binding collective agreements concerning one or more sectors of activity, where the length of the posting does not exceed one month.

e. Member States may provide for exemptions to be granted from the first subparagraph of paragraph 1(b) (annual holidays) and (c) (minimum pay) in the cases referred to in Article 1(3)(a) (subcontracting) and (b) (group) on the grounds that the amount of work to be done is not significant.

\section{Translation and Notification}

An action against the Federal Republic of Germany was brought by the European Commission before the Court of Justice on 29 November 2004 in order to (1) declare that, by providing that the Federal Republic of Germany has failed to fulfil its obligations under Article 56 TFEU as...

a. foreign undertakings are obliged to have the employment contract (or the documents required, pursuant to Directive 91/533/EEC, under the law of the State where the employee is resident), pay slips, time sheets, proof of payment of wages, and all other documents required by the German authorities, translated into German;

b. foreign employment agencies are obliged not only to give prior notification each time a worker is posted to a user of the worker's services in Germany, but also each time a worker starts a new job on a building site at the request of the user of his services...

The Court declared that in enacting a provision, such as paragraph 3(2) of the law on posting workers (Arbeitsnehmer-Entsendegesetz) of 26 February 1996, under which foreign temporary employment agencies are required to declare, not only the placement of a worker with a user of his services in Germany, but also any change relating to the place of employment of that worker, the Federal Republic of Germany had failed to fulfil its obligations under Article 49 EC.

The Commission contends that furthermore certain provisions of the Arbeitnehmer-Entsendegesetz (Law on the Posting of Workers) ('the AEntG'); which transposed Directive 96/71/EC on the posting of workers into national law do not comply with certain provisions of that directive. 
Rules relating to the obligation of employers established in a Member State other than Germany to translate documents.

In the Commission's view, the requirement for documents to be translated is appropriate to meeting Germany's monitoring needs However, having regard to the cooperation on information provided for by Article 4 of the Directive on the posting of workers, the obligation to translate all documents is no longer necessary and is therefore too far-reaching.

Rules relating to the obligation of employment agencies established in a Member State other than Germany to notify the competent authorities of the change before each transfer of a posted worker from one building site to another one are equally unacceptable.

Even if the obligation of employment agencies established outside Germany to notify each change has been slightly amended, the Commission is of the view that there is still unequal treatment, as, in the case of employment agencies established in Germany, the obligation to notify each change falls on the user of the worker's services, while in the case of employment agencies established outside Germany that obligation falls in principle on the supplier of labour and can be transferred to the user of the worker's services only by means of a contractual agreement. This unequal treatment constitutes an inadmissible restriction on the freedom to provide services within the meaning of Article 56 TFEU.

\section{The 2014 Directive on Enforcement of Posted Workers Rights}

\subsection{General background}

The new Posting of Workers Enforcement Directive will safeguard respect for posted workers' rights in practice and strengthen the legal framework for service providers. Member States have to implement the new Enforcement Directive in their national legislation no later than two years and twenty days after its publication in the EU's Official Journal.

The new Enforcement Directive will help to ensure that the posting directive's rules are better applied in practice, especially in some sectors such as construction and road haulage, where for example so-called 'letter box' companies (without any real economic activity in their 'home' country) have been using false 'posting' to circumvent national rules on social security and labour conditions. It will also improve the protection of posted workers' rights by preventing fraud, especially in subcontracting chains where posted workers' rights are sometimes not respected. 
In particular, the Enforcement Directive:

- increases the awareness of workers and companies about their rights and obligations as regards the terms and conditions of employment;

- improves cooperation between national authorities in charge of posting (obligation to respond to requests for assistance from competent authorities of other Member States - a two working day time limit to respond to urgent requests for information and a 25 working day time limit for non-urgent requests);

- clarifies the definition of posting so as to increase legal certainty for posted workers and service providers, while at the same time tackling 'letter-box' companies that use posting to circumvent the law;

- defines Member States responsibilities to verify compliance with the rules laid down in the 1996 Directive (Member States designate specific enforcement authorities responsible for verifying compliance; and Member States where service providers are established need to take necessary supervisory and enforcement measures);

- requires posting companies to:

- designate a contact person for liaison with the enforcement authorities;

- declare their identity, the number of workers to be posted, the starting and ending dates of the posting, the address of the workplace and the nature of the services;

- keep basic documents available such as employment contracts, payslips and time sheets of posted workers;

- improves the enforcement of rights, and the handling of complaints, by requiring both host and home Member States to ensure posted workers, with the support of trade unions and other interested third parties, can lodge complaints and take legal and/or administrative action against their employers if their rights are not respected;

- ensures that administrative penalties and fines imposed on service providers by one Member State for failure to respect the requirements of the 1996 Directive can be enforced and recovered in another Member State. Sanctions for failure to respect the Directive must be effective, proportionate and dissuasive.

\subsection{Linguistic Requirements}

\section{A. Information}

According to article 5, 1 of the enforcement directive Member States shall take the appropriate measures to ensure that the information on the terms and conditions of employment referred to in Article 3 of Directive 96/71/EC which are to be applied and complied with by service providers is made generally available free of charge in a clear, transparent, 
comprehensive and easily accessible way at a distance and by electronic means, in formats and in accordance with web accessibility standards that ensure access to persons with disabilities and to ensure that the liaison offices or other competent national bodies referred to in Article 4 of Directive 96/71/EC are in a position to carry out their tasks effectively.

According to Article 5, 2 (c) of the enforcement directive Member States shall make the information available to workers and service providers free of charge in the official language(s) of the host Member State and in the most relevant languages taking into account demands in its labour market, the choice being left to the host Member State. That information shall be made available if possible in summarised leaflet form indicating the main labour conditions applicable, including the description of the procedures to lodge complaints and upon requests in formats accessible to persons with disabilities; further detailed information on the labour and social conditions applicable to posted workers, including occupational health and safety, shall be made easily available and free of charge.

This puts quite a heavy burden on certain member states, like Belgium, where there are three official languages (Dutch, French and German). On top of that there is also the obligation to make the information available in the most relevant languages taking into account demands in its labour market. E.g. in Belgium, certain collective agreements, generally binding, are only available in one language, e.g; Dutch. Should they now be translated in French and German and in other relevant languages. There are Flemish and French decrees involving employment matters... Do they all have to be translated?

\section{B. Monitoring compliance}

According to Article 9, 1 of the enforcement Directive, Member States may only impose administrative requirements and control measures necessary in order to ensure effective monitoring of compliance with the obligations set out in this Directive and Directive 96/71/EC, provided that these are justified and proportionate in accordance with Union law.

For these purposes Member States may in particular impose the following measures:

a. an obligation for a service provider established in another Member State to make a simple declaration to the responsible national competent authorities at the latest at the commencement of the service provision, into (one of) the official language(s) of the host Member State, or into (an)other language(s) accepted by the host Member State, containing the relevant information necessary in order to allow factual controls at the workplace, including:

(i) the identity of the service provider;

(ii) the anticipated number of clearly identifiable posted workers; 
(iii) the persons referred to under points (e) and (f);

(iv) the anticipated duration, envisaged beginning and end date of the posting;

(v) the address(es) of the workplace; and

(vi) the nature of the services justifying the posting;

b. an obligation to keep or make available and/or retain copies, in paper or electronic form, of the employment contract or an equivalent document within the meaning of Council Directive 91/533/EEC, including, where appropriate or relevant, the additional information referred to in Article 4 of that Directive, payslips, time-sheets indicating the beginning, end and duration of the daily working time and proof of payment of wages or copies of equivalent documents during the period of posting in an accessible and clearly identified place in its territory, such as the workplace or the building site, or for mobile workers in the transport sector the operations base or the vehicle with which the service is provided;

c. an obligation to deliver the documents referred to under points (b), after the period of posting, at the request of the authorities of the host Member State, within a reasonable period of time;

d. an obligation to provide a translation of the documents referred to under point (b) into (one of) the official language(s) of the host Member State, or into (an)other language(s) accepted by the host Member State.

\section{Conclusions}

Each "people" has its own language and culture. We live in a global and multi-cultural world. Unity and diversity prevail. How to reconcile them?

Can certain groups protect their language, maintain and strengthen it by making the use of its language mandatory, so in the case of employment relations? Such a regulation benefits the employees of that linguistic group, promotes their internal and social cohesion and allows the local social inspection and administration to easily control the social policy of the enterprises, since they master the language used. But this is not the end of the story. What about workers from other countries, who are not familiar with the language in other working countries.

The EU stands for unity and diversity. Protective measures regarding languages are acceptable when they are proportionate and not more than necessary. In case of teaching a language, it is evident that the organizer can ask that the professor masters the language. But is this also the case regarding employment relations, which are trans-border, especially within the European Union, which requires equal treatment and no discrimination in case of freedom of movement of workers or freedom of services? 
In the Netherlands, to give one example, no special legislation on languages prevails, but practice indicates that employment contracts are made in Dutch. And are also signed by e.g. Polish workers. In Flanders, Belgium, in 1973 a Decree was promulgated making Dutch the mandatory language for all written and oral, collective and individual relations. In the Alton Las case the European Court of Justice ruled that the Flemish Decree was contrary to the free movement of workers and the suggestion was made that the employment contract should be made in a language both parties understand. But, can this work in practice? The Flemish Decree of 1973 was amended in the sense that employment contracts need to be drafted in Dutch but that an additional version can be made in one of languages of the countries of the European Economic Area. In case of discrepancy between contracts, the Dutch text prevails. But is this appropriate? It does not guarantee that both parties understand the same language. Moreover, what about the other documents and acts, which regulate the employment relationship, like work rules, collective agreements, dismissal and so on? How far does one have to go? A company cannot work in 20 languages.

Also the new directive of 2014/54 on freedom of movement of workers (in more than one official Union language taking into account demands in the labour market) and the enforcement directive on posting of workers (2014) foresee translation of applicable rules to the posted workers in the national language(s) and eventually other languages, which seem appropriate. Again this seems to be very burdensome in countries like Belgium where three national languages prevail. Do certain documents, like an extended collective agreement need to be translated in three languages, plus other language according to practice.

The problem is far from solved. It seems to me that in enterprises, the national language should prevail, with translation when necessary of individual documents, like the employment contract and the dismissal document. The solution we are looking for is respect for the diversity, seeing to it that employer and employee understand each other as far as the basic employment conditions - in individual documents - are in a language the worker understands.

And what do we do with workers, who are illiterate, who can, in other words, neither read nor write?

One should also realize that translations are not easy, as the translator should not only know the language, but also be familiar with employment relations ${ }^{1}$. So one has to be extremely cautious.

We have a long way to go.

${ }^{1}$ An example: some of the monographs of IELaws are translated in Chinese. Some of my former Chinese assistants drew my attention to the fact that the translator failed with the translation of certain essential words. So, trade-unions were literally translated into business associations. How wrong can one be. 


\section{Swoboda świadczenia usług w UE a używanie języków}

\section{Streszczenie}

Wszyscy ludzie mają własne języki i kulturę. Żyjemy w globalnym i wielokulturowym świecie. Jednolitość i zróżnicowanie zarazem przeważają. Jak je rozwiązywać?

Czy pewne grupy mogą chronić swój język, podtrzymywać go i umacniać czyniąc obowiązkowym jego stosowanie, także w wypadku stosunków pracy? Takie regulacje dają korzyści danej grupie językowej, wspierają jej wewnętrzną i społeczną spójność, a także pozwalają lokalnej inspekcji i administracji na łatwą kontrolę polityki społecznej przedsiębiorstw, ponieważ są biegłe w stosowanym języku. Nie jest to jednak koniec tej historii. Należy zapytać o pracowników z innych państw, którzy nie znają języka obowiązującego w państwach, w których pracują.

Unia Europejska popiera jedność i różnorodność. Środki ochronne dotyczące języków mogą być akceptowane, gdy są proporcjonalne i nie wykraczają poza granice konieczności. W razie nauczania języka, organizator może domagać się, aby nauczyciel go doskonalił. Czy można to jednak odnieść do transgranicznych stosunków pracy, zwłaszcza w Unii Europejskiej, wymagającej równego traktowania i niedyskryminowania w odniesieniu do swobody przemieszczania się pracowników i swobody usług?

Tłumaczenie z języka angielskiego - Zbigniew Hajn 